Shavkun, I. and Dybchinska, Ya. (2019). "Efficient manager: creative dimension", Management and entrepreneurship: trends of development, 2 (08), pp. 47-59. doi: https://doi.org/10.26661/2522-1566/2019-2/08-04

\title{
MANAGEMENT
}

Received:

5 March, 2019

1st Revision:

28 March, 2019

Accepted:

2 April, 2019
UDC: $005.95-051: 316.653$

DOI https://doi.org/10.26661/2522-1566/2019-2/08-04

*Corresponding author email: shavkun@znu.edu.ua

\section{EFFICIENT MANAGER: CREATIVE DIMENSION}

IRYNA SHAVKUN, Doctor of Philosophy, Professor, Dean of the Faculty of Management, Zaporizhzhia National University, Zaporizhzhia, Ukraine, ORCID ID: https://orcid.org/00000003-2227-9754

YANA DYBCHINSKA, PhD in Philology, associate professor, Head of the Chair of Business Communication, Zaporizhzhia National University, Zaporizhzhia, Ukraine, ORCID ID: https://orcid.org/0000-0002-0992-7326

Abstract. Creativity is a foundational aspect of human society. Management as specific sphere of human activity is sure to imply creativity on the one hand - to develop certain management decisions, on the other - to encourage personnel to the necessary in the top management's opinion actions. Such involvement requires from the organization's qualified management constant appeal to the creativity that may be considered intrinsic of each employee at least at the intuitive level. The purpose of this article is to analyze the problem of creative potential of the organization and identify the attributes of the creative manager. The specific paper objectives are: to review most important approaches to the conceptualization of the notion of creativity; to refine and extend the creative nature of management. To substantiate the theoretical positions and reasoning of the conclusions general scientific methods are used, including system, abstract-logical approach, as well as methods of formalization, analysis and synthesis of information, comparative analysis and expert assessments, graphical visualization of factual information. The study contributes to a broader understanding of the organizational creativity as the efficient management imperative. The object of the research is the creative attributes of efficient manager. The subject of the study is the organizational and economic relations arising in the process of managing intellectual and creative resources in business organizations. The studies focus on mapping the understandings of theoretical and conceptual aspects of creativity in management as conceived by various theorists and practitioners. Proceeding from the critical synthesis of the creative management discourses it is attempted to provide an outline of the attributes relevant in seeking the main competencies of the creative manager. The phenomenon problematizing makes it possible to identify the groups of competences of the creative manager as practical contribution.

Keywords: efficient management, creative manager, creativity, innovation, organization

JEL Classification: M12, M54, O15

\section{INTRODUCTION}

In almost any area of production, the winner is ultimately one who has the creative potential.

In the past managers had a strong desire for clear execution. A good leader was considered to be one who was able to execute orders of higher authorities or instructions, standards, consistent with accepted types of business behavior. Modern trends in the development of management give rise to new challenges for the manager. Increasing intensity of competition requires new marketing ideas, 
improving advertising, more active use of non-traditional BTL tools, mosquito and event marketing etc. It directly results in the use of non-standard creative ideas and solutions in business and management. In the field of management it has become traditional to use reengineering and controlling, involving a creative approach to solving traditional management problems through the use of information technologies to improve productivity, and the development of new methods of forecasting market situations necessary to adjust the strategy of companies. Currently, creativity is becoming a constant practice and the main source of the organization competitive advantage (Kruglov, 2004).

It should be emphasized that the creative potential of the organization is not just the sum of the creativity of the individual employees. Among its constituent parts there are also the cumulative creativity of a team or group and creativity arising out of organization different structural components (Blomberg, 2016). To manage the organization creative potential means its regular analyzing, planning activities for the implementation and development of this potential, appropriate monitoring and evaluation of the company's creative potential efficiency.

Today, the concept of a creative manager or a manager of a research and strategic type is born. This need is realized in the most diverse forms: organization management, methodology development, management decisions, restructuring of firms, human capital formation, etc. But one of the implications of this need is the emergence of managers who could be called creative managers (Pronina, 2018; Florida, 2014). Their peculiarity is the increased attention to the research approach in the assessment of external and internal situations, in the development of strategic management decisions in conditions of uncertainty and competition. While the classic manager acts as a supervisor, officer, follower, or account supervisor, creative manager today plays the role of coach, team leader, coordinator, assistant or a visionary. Hence it is essential to highlight and substantiate the most significant attributes of the creative manager.

\section{LITERATURE REVIEW}

To begin with, the objectives of this study require the conceptualization of the notion of "creativity" and its derivatives.

According to Merriam-Webster's Learner's Dictionary "creativity" means: 1) the skill and imagination to create new things (synonyms: cleverness, creativeness, imagination, imaginativeness, ingeniousness, ingenuity, innovativeness, invention, inventiveness, originality); 2) the ability to form mental images of things that either are not physically present or have never been conceived or created by others (synonyms: contrivance, fancy, fantasy or phantasy, ideation, imagination, imaginativeness, invention, inventiveness, originality).

Creativity is a process that can be observed only at the intersection where individuals (genetic makeup, talents, experience), social system (community of practice), and cultural system (knowledge, tools, values, practices). For creativity to occur, a set of rules and practices must be transmitted from the cultural system to the individual. The individual must then produce a novel variation in the content of the domain. The variation then must be selected by the social system for inclusion in the domain (Henry, 2006). 
Shavkun, I. and Dybchinska, Ya. (2019). "Efficient manager: creative dimension", Management and entrepreneurship: trends of development, 2 (08), pp. 47-59. doi: https://doi.org/10.26661/2522-1566/2019-2/08-04

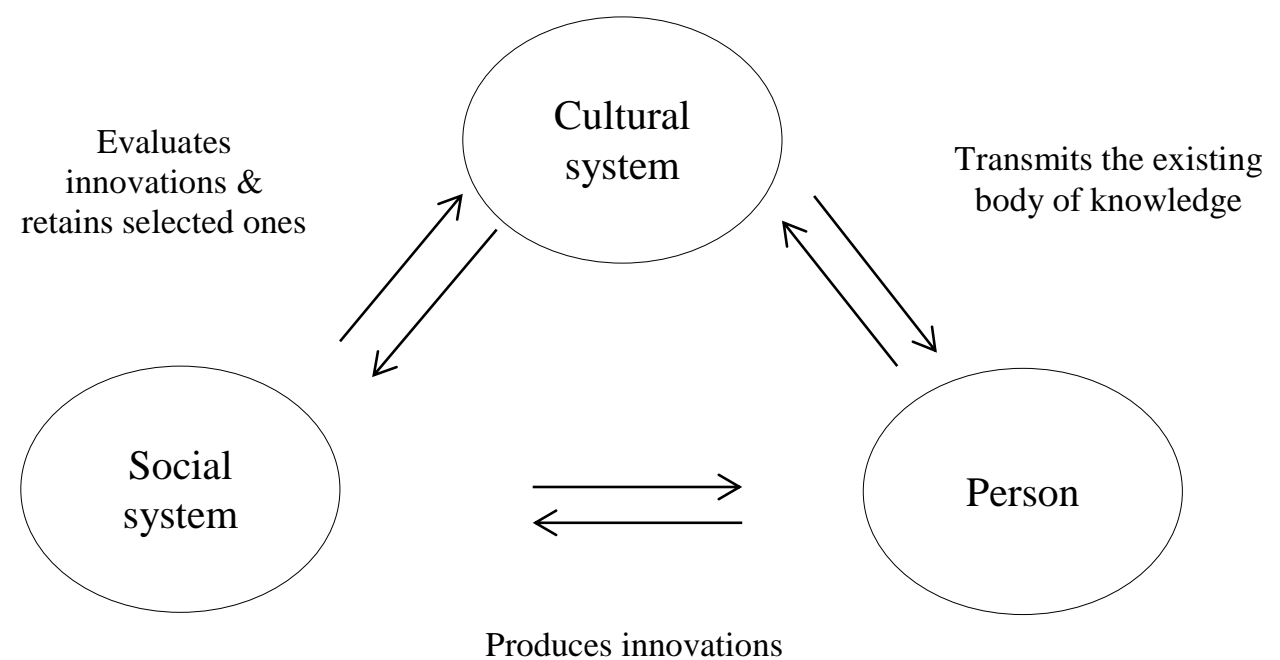

Figure 1. A systems model of creativity

Creativity as a concept has many meanings: 'newness,' 'originality,' 'uniqueness,' and 'difference'. Creativity can, for instance, be defined as a creative use of existing knowledge (Henard and McFadyen, 2008) or a as a new combination of existing ideas (Furr, Dyer and Christensen, 2014), as a capability to see associations between seemingly nonrelated things (Fong, 2006) or as an ability to create new combinations between fields of knowledge (Mahmoud-Jouini and Charue-Duboc, 2008) Creativity may be defined as 'the formation of novel, appropriate and useful ideas by individuals or small groups' (DiLileo and Houghton, 2006). Creativity at organizational level may be defined as the creation of a valuable, useful new product, service, idea, procedure, or process by individuals working together in a complex social system (Pinkun, 2016).

Typologically there can be distinguished two groups of approaches to the analysis of the phenomena.

The first is focused on the search for sources, on the process and includes: the psychoanalytic approach (creativity is the result of intrapersonal conflicts); the humanistic approach (creativity is the realization of creative potential in the conditions of internal and external obstacles elimination); the psychometric approach (the individual creative potential is formed genetically and can be determined by tests).

The second group roots in associationism as the idea that mental processes operate by the association of one mental state with its successor states. Exploring the emergence of new ideas and the development of the people and situations that bring them to fruition, "associationists" stick to understand human creativity as a result of the ability to find remote associations while searching for the problem solution (Mescon, Albert and Khedouri, 2015).

With this in mind, the concept of "creativity" can be interpreted as both a process leading to the creation of something new and person's potential (internal resource). Otherwise speaking, creativity can be tackled as the ability of a person to abandon stereotypes of thinking while identifying new ways of solving problems by means of transforming information from the subconscious into the sphere of consciousness. In contrast to logical thinking, which is a link in one chain and gives a mathematically verified solution, creative thinking is thinking with a shifted focus that can admit both chaos and intuition as well as sudden insights. Herewith, the mentioned processes remain controlled (Goodman and Dingli, 2017; Gillian, 1997).

Thus, creativity ceases to be a concept characteristic only of the artist or writer. It penetrates into all spheres of our life, acquiring new applications. 
Management as science, that emerged on the basis of practical management experience, is based on the entire amount of knowledge about management accumulated by mankind and encompasses concepts, theories, principles, methods and forms of management. The main objectives of management as science are the following: to conceptualize the nature of managerial work; to clarify the cause-and-effect relations in this area; to identify factors and conditions of efficient joint work; to develop the methods of effective operational management; prognosticate events and elaborate methods of the organization strategic management and policy.

Modern management exploration puts special emphasis on the transformation of management into science. However, on the way to this goal there occur disputes between scientists and practitioners, between heuristics and analytics about the possibility to achieve it with regard to the following assumptions:

- organization is a complicated social and technical system;

- human resources are the main factor in the effectiveness of its functioning;

- practical management can be mastered only through experience, perfectly acquired by people with appropriate talent;

- decision-making commonly takes place in conditions of insufficient information;

- while implementing decisions the manager is not guaranteed from errors incorporating possible future risks.

In other words, the main reasoning of skeptics is reduced to the statement that multiple environmental factors that affect the organization management makes it impossible to correctly identify all the relations between the environment and the organization. Management by definition assumes the need to develop an adequate assessment of the approach to long-term goals after implementing operational decisions by the manager. Such an assessment can be made in different ways in the field of the continuum, that is limited to two alternative approaches: analytical and intuitive (Mescon, Albert and Khedouri, 2015).

Here it is appropriate to refer to the works of the founders of scientific management. So F. Taylor said about the "constructive imagination which enables a man to use the new facts that are stored in his mind in getting around the obstacles oppose him and in building up something useful in spite of them" (Taylor, 1919). Regarding management as "the art of administration" Henri Fayol, another father of scientific management, alongside with his 14 general principles defined five functions of management that are still seen as relevant to organizations today. These five functions focus on the relationship between personnel and its management and they provide points of reference so that problems can be solved in a creative manner. According to Henri Fayol the function of planning consists in the ability of looking ahead. Drawing up a good plan of action is the hardest of the five functions of management because this requires an active participation of the entire organization. With respect to time and implementation, planning must be linked to and coordinated on different levels. Planning must take the organization's available resources and flexibility of personnel into consideration as this will guarantee continuity. Fayol was convinced that "to manage is to foresee" (Fayol, 1949).

Thus alongside with other most important determinants of managerial competences there is to be found the ability to trust your intuition as well as the courage to make decisions in different conditions of any complexity. Both innate and acquired qualities are viewed basic for the art of management. In particular, it is talent, intuition, imagination, creativity, willingness to accept the new. The art of management consists in creative use of the accumulated experience and acquired knowledge in practice.

While developing management decisions it is advisable to resort to the concept of "creative" and "heuristic" management. The first implies management activity based on moving ("drifting") criteria of goal-setting. While heuristic (from the Greek heuristro - "I find, open") provides for the management of the individual, self management. Creative management is effective when the created intellectual product becomes the result of the collective activity. Heuristic management 
Shavkun, I. and Dybchinska, Ya. (2019). "Efficient manager: creative dimension", Management and entrepreneurship: trends of development, 2 (08), pp. 47-59. doi: https://doi.org/10.26661/2522-1566/2019-2/08-04

proceeds from individual goal-setting and means to manage the activity of the individual as a participant of the intellectual product creation (Kirsanov, 2011).

The above mentioned definition of heuristic management may be found somehow controversial. Different types of management decisions - standard (typical), creative, heuristic - develop respectively three types of thinking - convergent, divergent and lateral. Therefore, heuristic solutions are solutions based on lateral thinking that tries to algorithmize the creative process. Considering heuristics as a science of discovery actually involves algorithmization of the creative process. This interpretation of heuristic solutions is seen as most correct since creative activity characterizes not only collective, but also individual work. Accordingly heuristic activity is an activity of both within the team and individual.

Creative management primarily means managing innovations. The latter implies ideas, methods and inventions that are used to improve current activities or introduce a new idea or method. While in most cases creativity is identified with the generation of ideas, innovation implies the transformation of ideas into new products and services that realize the results of creativity. Innovation suggests purposeful change, an attitude that reflects the ability to imagine something that doesn't exist, or a process that starts with an idea and ends with an implementation. In fact, these two concepts overlap. Innovations have become increasingly important to corporations over the past decade, given business changes such as increased technological capacity and its rapid expansion.

The overall innovation process includes the stages of product development, service, result, technology and their commercialization. Accordingly, creative management is the study and practice of management, based on the theories of creative processes and their application at the individual, group, organizational and cultural level (Dawson and Andriopoulos, 2017).

Creative management is closely connected with the development of such areas as human resource management, strategic management, innovation management, self management, organizational culture, marketing. The concept of the management of the organization creative potential is based on the general theory of management and focuses the attention of managing subjects on a number of tasks. Among them it is worth mentioning: using the employees' creative potential, developing and managing their decision-making, improving their skills, implementing modern methods of creative thinking in the management process, providing creative atmosphere in the team, developing the process of self-realization and self-improvement of staff.

The creative potential of the organization is understood as its ability to make and implement creative management decisions that contribute to achieving organization's goals and forming unique competitive advantages by means of using both available and attracted resources. It should be emphasized that the creative potential of the organization is not a mere sum of the creative potential of its employees. It is characterized by a synergetic effect from the realization of the creative potential of employees and the use of organizational and economic mechanism to develop this potential (McGuinness, 2008). The creative potential of managing the organization requires its regular analysis, planning of activities for the implementation and development of this potential, appropriate monitoring and evaluation of its use effectiveness.

\section{PAPER OBJECTIVE}

The purpose of this article is to analyze the problem of creative potential of the organization and identify the competences of the creative manager. The specific paper objectives are: to review most important approaches to the conceptualization of the notion of creativity; to refine and extend the creative nature of management. 


\section{RESULT AND DISCUSSION}

The most important event of the late XXth century was the formation of the foundations of postindustrial society. This process involves first subtle, and then more active and clear departure from the traditional hierarchical organization in the direction of economic motivation of human activity.

At the time when the corporation modernization became an integral part of most global changes in the social environment as a whole, the corporation became "sociologized" ("sociologizing mode") by definition. A modern corporation is more than a set of processes, products and services, and even more than an association of working people. It is primarily a human community. Like all communities, it develops specific forms of culture - the so-called "corporate culture". Main changes in the structure and form of the corporation occurred as a result of considering the internal rather than external aspects of the company's activities - the employees' needs and dignity rather than the consumers' priorities. Today when the information revolution generates new products faster than it is necessary for the society to realize their need, the key to succeed in the competition is not to follow the demand but to form it. Thus, it becomes urgent to mobilize the creative potential of the company's employees to ensure its market prosperity.

Growing competition, revolutionary changes in technologies force companies to develop unconventional approaches, to look for fundamentally new solutions of traditional problems. For example reducing the volume of routine labor through the delegation of part of the managerial work to computers, machines and automata frees up time for the staff, including management, to devote to creative activities. The possibility of free creative self-realization is no less valuable than the level of remuneration.

In vertically integrated companies with a complex organizational structure professional managers have to rely on intuition due to the risks because of insufficient information for rational decisions approval. Therefore, to develop creative decision- making methodology is one of the urgent tasks of management. Such solutions provide organizations with unique competitive advantages, improvement of marketing activities, advertising, "public relations", expansion of markets.

Nowadays management theory is increasingly tackling the problem of manager's creative potential optimal use in the organization. In the conditions of industrial society creativity was not a significant factor of production. But it was important to increase the quantity but not the quality of goods consumed. Consequently, primitive and limited forms of creative activity beyond production entailed almost reduction of any individuality in the workplace. This fully met the requirement to ensure the growth of produced goods by means of taylorizm and conveyor system and was put an end to by the economic crisis of the late 1920s.

Decentralization and demassification of production in the second half of the last century due to new technologies rapid expansion caused decentralization and de-hierarchization of the management system. The shift of responsibility to the grass-roots level of management resulted in increasing decision-making freedom for staff that in turn led to their creativity growth. This process can be defined as "the revolution of participation", that occurs place first at the factory level, but is able to "spread to organizations of all types" (Bell and Krystol, 1981).

Along with art, science and other spheres of human activity, creativity increasingly penetrates into the sphere of management. Taking into account the fact that creative thinking of a person is a cultural and civilizational phenomenon, historically there were two approaches in its study. The first approach was aimed at rationalizing the operation procedures with the object (reflections on being, on the object and its forms). The second one envisaged the analysis of thinking as activity, ability, state of the subject (reflections on being, on the subject and subjectivity). These two approaches are to be found in such dichotomies of creativity as logic and intuition, a systematic search and insight, the algorithmical and the heuristic in the creative process, reflexibility and unconsciousness in creative acts, formalizability and nonformalizability of creativity etc. 
Shavkun, I. and Dybchinska, Ya. (2019). "Efficient manager: creative dimension", Management and entrepreneurship: trends of development, 2 (08), pp. 47-59. doi: https://doi.org/10.26661/2522-1566/2019-2/08-04

It is worth emphasizing that in Western European cultural tradition preference was given to the tendency to consider creativity from the standpoint of the first approach. As a result, there occurred a paradox. Unlike other types of the objectified knowledge rational knowledge about creativity could not find application, because it did not transform into technology (just as knowledge about natural processes transformed into production technologies), that would allow a person to strengthen own creative abilities. The study of logics did not guarantee any enhancement of logical thinking abilities as well as the research of algorithms, procedures of creative thinking did not turn a person into a smoothly operating creative machine. And ultimately your awareness of outstanding figures' creative activity experience didn't make you a genius. That is why the knowledge of creative thinking in the continuous process of its accumulation, as a rule, remained on the periphery of the development of social practices and technologies. To crown it all due to the fact that the implicit side of creativity defies any rationalization, it is considered as a subject of psychology. The latter almost never encountered with social practice. Therefore, this approach to creativity oddly enough happened to be absolutely needless for management.

However, in modern management there is to be found another situation. Today it is advisable to talk not only about the dominance of the problems of creativity and creative thinking in management, but also to consider modern management as a space for the transformation of creative thinking from a purely psychological phenomenon to a factor of cultural and civilizational importance. Today there are brought to the fore such topical issues as forming new cultural meanings of creative thinking and of the new models of its understanding.

This is largely due to the change in the position of the owner. The notion of "ownership" is increasingly being replaced by the notion of "accessibility" to the network of services and goods that define people's lifestyles. Today, the competition is won not by those who produce quality goods or services, but by those who are able to create new experiences for groups of people uniting in communities of interest. The subject of commoditization as transformation into a product is neither things nor even services as Peter Drucker constantly reminds, analyzing the changes of capitalism during the 50's-80's of the twentieth century. The subject of commoditization is interpreted as new personal experience in relation to a particular brand regarded trustworthy by consumer.

Therefore, if in classical capitalism the main thing was to appeal to the knowledge of natural processes that could be transformed into technologies for the production of goods to provide material conditions of life, today we need humanitarian knowledge, knowledge about the ways and style of human life, that cannot be fully objectified. On the contrary it can only be obtained as if trying on different experiences of life (this is what advertising itself does). This changes the cognitive framework of thinking, including epistemological management models. With regard to efficient management achievements the models of thinking embedded in the activity, situation, or directly growing from the context and configuration fields and states of human life acquire increasing recognition.

Creativity and creative thinking are largely becoming synonymous with such manager's abilities as flexibility, adaptability, mobility, aptitude of self-creation. It implies the emancipation of capabilities and demand efforts to change mental frameworks. This is the only way to convert tastes, habits, stereotypes and images into the elements of strategy and tactics of thinking. New unique opportunities of life actualize for the manager such competences as the ability to integrate into the lifestyle of another person, to understand the other, to contextually simulate and reproduce possible existential configurations. All this is possible mainly due to theater technologies, that are actively applied in business and advertising.

Referring to the manager of creative type and his intrinsic characteristics it is appropriate to commence the conceptualization with the attempt to solve the dilemma: What type of manager is most preferable now: the one who clearly executes the orders of the higher management - or the one who is more independent in decision-making? Until recently, the first option was undoubtedly 
in the lead. However, the requirements of managers have changed somewhat recently. Among the indispensable features of modern management - the need to generate new ideas, insights, research, strategic decision-making. Hence there is a demand for a manager-researcher, a manager of a strategic type.

Such type is characterized by a number of attributes. Among the most determinant ones there are to be defined creativity, trainability, reflexivity.

Proceeding from the thesis that creativity is the process of identifying hidden opportunities and creative use of their potential in a certain area, creatives are people who are not only able to solve complex intellectual problems, but also feel the need for it. Trainability in a broad sense is susceptibility to learning effects in a new situation; in the narrow sense - an indicator of the speed and quality of learning, skills. Reflexivity means the ability to general arbitrary self-regulation of intellectual activity or (in a narrower sense) a measure of the effectiveness of "cognitive monitoring" for it.

However in addition to this, discipline, internal self-control and organization are equally important. Readiness to overcome difficulties and seek to gain victory until the moment of complete satisfaction with the result - these are the signs of creative potential. It means that you not only can work with knowledge, products and trends but interpret them in a new way, forming a whole. At the same time, it ensures indissoluble continuity between activity and intelligence. Moreover, it forms the basis for the new features of manager's intellectual activity.

\section{CONCLUSION}

Creativity has become an essential prerequisite for strategic management since the development of the organization's mission and strategy is a process of creativity, even art. Creativity and creative thinking are largely becoming synonymous with such manager's abilities as flexibility, adaptability, mobility, aptitude of self-creation. New unique opportunities of life actualize for the manager such competences as the ability to integrate into the lifestyle and comprehend another person, to contextually simulate and reproduce possible existential configurations. Providing the need of modern management to generate new ideas, insights, research, strategic decision-making there is a demand for a manager-researcher, a manager of a strategic type. Such type is characterized by a number of attributes. Among most determinant there are creativity, trainability and reflexivity.

\section{REFERENCES}

Bell, D. and Krystol, I. (ed.) (1981). Models and reality in economic discourse. In the crisis in economic theory, New York: Basic Books. Inc., [Online], available at: https://www.nationalaffairs.com/storage/app/uploads/public/591/ee4/81d/591ee481da89340558 6295.pdf, (Accessed 1 February 2019).

Blomberg, A. (2016). Organizational creativity - hegemonic and alternative discourses, Turku School of Economics, Series A, [Online], available at: https://www.utupub.fi/bitstream/handle/10024/119889/Ae1_2016.pdf?sequence=2\&isAllowed= y, (Accessed 1 February 2019).

Dawson, P. and Andriopoulos, C. (2017). Managing Change, Creativity and Innovation, [Online], available

at:

https://www.researchgate.net/profile/John_Edmonstone/publication/321884773_Managing_cha nge_creativity_and_innovation/links/5a4a16c70f7e9ba868ae03f5/Managing-change-creativityand-innovation.pdf?origin=publication_detail, (Accessed 1 February 2019).

DiLileo, T. C. and Houghton, J. D. (2006). "Maximizing organizational leadership capacity for the future: toward a model of selfleadership, innovation and creativity" Journal of Managerial 
Shavkun, I. and Dybchinska, Ya. (2019). "Efficient manager: creative dimension", Management and entrepreneurship: trends of development, 2 (08), pp. 47-59. doi: https://doi.org/10.26661/2522-1566/2019-2/08-04

Psychology 21(4), pp. 319-337, [Online], available at: http://dx.doi.org/10.1108/02683940610663114, (Accessed 1 February 2019).

Fayol, H. (1949). General and industrial management, Pitman, London, [Online], available at: https://www.researchgate.net/profile/Cameron_Guthrie/publication/273695543_Henri_Fayol_th e_manager/links/55091e060cf26ff55f84c06d/Henri-Fayol-the-manager.pdf, (Accessed 1 February 2019).

Florida, R. (2014). The Rise of the Creative Class. Revisited. Revised and Expanded Kindle Edition, [Online], available

at: https://docs.google.com/document/d/18B3I3s9NVxaPhFWtti575FkBDL1a2U7Sbm57cuEUvZU /edit, (Accessed 01 February 2019).

Fong, C.T. (2006). "The effects of emotional ambivalence on creativity", Academy of Management Journal, Vol. 49 (5), 1016-1030, [Online], available at: https://journals.aom.org/doi/10.5465/amj.2006.22798182, (Accessed 1 February 2019).

Furr, N., Dyer, J and Christensen C. M. (2014). "The Innovator's Method: Bringing the Lean Startup into Your Organization", Harvard Business Review press, [Online], available at: http://learn.theinnovatorsmethod.com/assets/innovators_method_ch1-

2411 aeacbd0800d5dce412a351be347f.pdf, (Accessed 1 February 2019).

Gillian, R. (1997). Creative Management of Creative Management: A Critical Systems Approach, A Thesis for the Degree of $\mathrm{PhD}$, [Online], available at: https://core.ac.uk/download/pdf/2731868.pdf, (Accessed 1 February 2019).

Goodman, M. and Dingli, S. (2017). Creativity and Strategic Innovation Management: Directions for Future Value in Changing Times, Routledge, [Online], available at: https://olipsone.com/download.php?q=creativity-and-strategic-innovation-managementgoodman-malcolm, (Accessed 1 February 2019).

Henard, D.H. and McFadyen, M.A. (2008). "Making knowledge workers more creative", Research Technology Management, Vol. 51 (2) 40-46, [Online], available at: https://www.tandfonline.com/doi/abs/10.1080/08956308.2008.11657494, (Accessed 1 February 2019).

Henry, J. (2006). Creative management and development (third edition), London, UK: Sage in association with The Open University, [Online], available at: http://perpustakaan.unitomo.ac.id/repository/Creative\%20Management\%20and\%20Developmen t.pdf, (Accessed 1 February 2019).

Kirsanov, K. (2011). "Creative and heuristic management and inventive creativity", Naukovedenie, No. 4, pp. 21-35, (in Russian). available at: https://naukovedenie.ru/sbornik9/9-6.pdf (Accessed 1 February 2019).

Kruglov, A. V. (2004). "Managing the creative potential of the company and its value in market competition", Problems of modern economics, No. 4 (12), pp. 15-23, [Online], (in Russian), available at: http://m-economy.ru/art.php?nArtId=565, (Accessed 1 February 2019).

Mahmoud-Jouini, S.B. and Charue-Duboc, F. (2008). "Enhancing discontinuous innovation through knowledge combination: the case of an exploratory unit within an established automotive firm", Creativity and Innovation Management, Vol. 17 (2), 127-135, [Online], available at: https://studies2.hec.fr/jahia/webdav/site/hec/shared/sites/jouini/acces_authentifie/articles\%20pu blies/CIM\%202008.pdf, (Accessed 1 February 2019).

McGuinness, M. (2008). Creative management for creative teams, e-book published by Mark McGuinness, London, [Online], available at: http://www.wishfulthinking.co.uk/2008/03/21/free-e-book-creative-management-for-creativeteams/, (Accessed 1 February 2019).

Merriam-Webster's Learner's Dictionary, [Online], available at: https://www.merriamwebster.com/thesaurus/creativity, (Accessed 1 February 2019). 
Mescon, M H, Albert, M. and Khedouri, F. (2015). Management, Harpercollins College Div; Subsequent edition. [Online], available at: https://storage.googleapis.com/moteoasemiloslav.appspot.com/management-by-michael-hmescon-1988-05-30-B01K2QU9B6.pdf, (Accessed 1 February 2019).

Pinkun, D. (2016). Kreativnyj menedzhment [Creative management], Moscow, Azbuka-Biznes, 240p., (in Russian).

Pronina, Z. Yu. (2018). "Creativity in the knowledge economy" [Kreativnosty v ekonomike znaniy], Creative Economy, 12(11), (in Russian), doi: 10.18334/ce.12.11.39646, available at: https://creativeconomy.ru/lib/39646, (Accessed 1 February 2019).

Sawyer, R. K., John-Steiner, V., Moran, S., Sternberg R. J., Feldman, D. H., Gardner H., Nakamura J. and Csikszentmihalyi M. (2003). Creativity and Development, Oxford University Press; 1 edition,

[Online], available

at: https://www.researchgate.net/publication/285924429_Creativity_and_Development], (Accessed 1 February 2019).

Taylor, F. W. (1919). The Principles of Scientific Management, Harper \& Brothers Publishers, New York and London, [Online], available at: https://wwnorton.com/college/history/americaessential-learning/docs/FWTaylor-Scientific_Mgmt-1911.pdf, (Accessed 1 February 2019).

\section{СПИСОК ВИКОРИСТАНИХ ДЖЕРЕЛ}

Кирсанов К.А. Креативный и эвристический менеджмент и изобретательское творчество. Интернет-журнал «Науковедение». №4. 2011. C. 21-35. URL: https://naukovedenie.ru/sbornik9/9-6.pdf (дата звернення 1.02.2019)

Круглов А.В. Управление креативным потенциалом компании и его значение в рыночной конкуренции. Проблемы конкурентоспособности в современной экономике. 2004. №4 (12). C.15-23. URL: http://ivansosh.ru/kniga-skachat/kreativniy-menedzhment-damrongpinkun.php (дата звернення 1.02.2019)

Пинкун Д. Креативный менеджмент. Москва: Азбука-Бизнес, 2016. 240с.

Пронина 3.Ю. Креативность в экономике знаний. Креативная экономика. 2018. Том 12. № 11. C. 1725-1732. doi: 10.18334/ce.12.11.39646 URL: https://creativeconomy.ru/lib/39646 (дата звернення 1.02.2019)

Bell, D. and Krystol, I. (ed.) (1981). Models and reality in economic discourse. In the crisis in economic theory, New York: Basic Books. Inc., [Online], available at: https://www.nationalaffairs.com/storage/app/uploads/public/591/ee4/81d/591ee481da89340558 6295.pdf, (Accessed 1 February 2019).

Blomberg, A. (2016). Organizational creativity - hegemonic and alternative discourses, Turku School of Economics, Series A, [Online], available at: https://www.utupub.fi/bitstream/handle/10024/119889/Ae1_2016.pdf?sequence=2\&isAllowed= y, (Accessed 1 February 2019).

Dawson, P. and Andriopoulos, C. (2017). Managing Change, Creativity and Innovation, [Online], available

at: https://www.researchgate.net/profile/John_Edmonstone/publication/321884773_Managing_cha nge_creativity_and_innovation/links/5a4a16c70f7e9ba868ae03f5/Managing-change-creativityand-innovation.pdf? origin=publication_detail, (Accessed 1 February 2019).

DiLileo, T. C. and Houghton, J. D. (2006). "Maximizing organizational leadership capacity for the future: toward a model of selfleadership, innovation and creativity" Journal of Managerial Psychology 21(4), pp. 319-337, [Online], available at: http://dx.doi.org/10.1108/02683940610663114, (Accessed 1 February 2019).

Goodman, M. and Dingli, S. (2017). Creativity and Strategic Innovation Management: Directions for Future Value in Changing Times, Routledge, [Online], available at: 
Shavkun, I. and Dybchinska, Ya. (2019). "Efficient manager: creative dimension", Management and entrepreneurship: trends of development, 2 (08), pp. 47-59. doi: https://doi.org/10.26661/2522-1566/2019-2/08-04

https://olipsone.com/download.php?q=creativity-and-strategic-innovation-managementgoodman-malcolm, (Accessed 1 February 2019).

Fayol, H. (1949). General and industrial management, Pitman, London, [Online], available at: https://www.researchgate.net/profile/Cameron_Guthrie/publication/273695543_Henri_Fayol_th e_manager/links/55091e060cf26ff55f84c06d/Henri-Fayol-the-manager.pdf, (Accessed 1 February 2019).

Florida, R. (2014). The Rise of the Creative Class. Revisited. Revised and Expanded Kindle Edition, [Online], available

at: https://docs.google.com/document/d/18B3I3s9NVxaPhFWtti575FkBDL1a2U7Sbm57cuEUvZU /edit, (Accessed 01 February 2019).

Fong, C.T. (2006). "The effects of emotional ambivalence on creativity", Academy of Management Journal, Vol. 49 (5), 1016-1030, [Online], available at: https://journals.aom.org/doi/10.5465/amj.2006.22798182, (Accessed 1 February 2019).

Furr, N., Dyer, J and Christensen C. M. (2014). "The Innovator's Method: Bringing the Lean Startup into Your Organization", Harvard Business Review press, [Online], available at: http://learn.theinnovatorsmethod.com/assets/innovators_method_ch1-

2411aeacbd0800d5dce412a351be347f.pdf, (Accessed 1 February 2019).

Gillian, R. (1997). Creative Management of Creative Management: A Critical Systems Approach, A Thesis for the Degree of $\mathrm{PhD}$, [Online], available at: https://core.ac.uk/download/pdf/2731868.pdf, (Accessed 1 February 2019).

Henard, D.H. and McFadyen, M.A. (2008). "Making knowledge workers more creative", Research Technology Management, Vol. 51 (2) 40-46, [Online], available at: https://www.tandfonline.com/doi/abs/10.1080/08956308.2008.11657494, (Accessed 1 February 2019).

Henry, J. (2006). Creative management and development (third edition), London, UK: Sage in association with The Open University, [Online], available at: http://perpustakaan.unitomo.ac.id/repository/Creative\%20Management\%20and\%20Developmen t.pdf, (Accessed 1 February 2019).

Mahmoud-Jouini, S.B. and Charue-Duboc, F. (2008). "Enhancing discontinuous innovation through knowledge combination: the case of an exploratory unit within an established automotive firm", Creativity and Innovation Management, Vol. 17 (2), 127-135, [Online], available at: https://studies2.hec.fr/jahia/webdav/site/hec/shared/sites/jouini/acces_authentifie/articles\%20pu blies/CIM\%202008.pdf, (Accessed 1 February 2019).

McGuinness, M. (2008). Creative management for creative teams, e-book published by Mark McGuinness, London, [Online], available at: http://www.wishfulthinking.co.uk/2008/03/21/free-e-book-creative-management-for-creativeteams/, (Accessed 1 February 2019).

Merriam-Webster's Learner's Dictionary, [Online], available at: https://www.merriamwebster.com/thesaurus/creativity, (Accessed 1 February 2019).

Mescon, M H, Albert, M. and Khedouri, F. (2015). Management, Harpercollins College Div; Subsequent edition. [Online], available at: https://storage.googleapis.com/moteoasemiloslav.appspot.com/management-by-michael-hmescon-1988-05-30-B01K2QU9B6.pdf, (Accessed 1 February 2019).

Sawyer, R. K., John-Steiner, V., Moran, S., Sternberg R. J., Feldman, D. H., Gardner H., Nakamura J. and Csikszentmihalyi M. (2003). Creativity and Development, Oxford University Press; 1 edition, [Online], available at: https://www.researchgate.net/publication/285924429_Creativity_and_Development], (Accessed 1 February 2019). 
Taylor, F. W. (1919). The Principles of Scientific Management, Harper \& Brothers Publishers, New York and London, [Online], available at: https:/wwnorton.com/college/history/americaessential-learning/docs/FWTaylor-Scientific_Mgmt-1911.pdf, (Accessed 1 February 2019).

\section{ЕФЕКТИВНИЙ МЕНЕДЖЕР: КРЕАТИВНИЙ ВИМІР}

ШАВКУН ІРИНА ГРИГОРІВНА, доктор філософських наук, професор, декан факультету менеджменту, Запорізький національний університет, м. Запоріжжя

ДИБЧИНСБКА ЯНА СТАНІСЛАВІВНА, кандидат філологічних наук, дочент, завідувач кафедри ділової комунікації, Запорізький національний університет, м.Запоріжжя

Творчість є основоположним аспектом людського суспільства. Менеджмент як особлива сфера людської діяльності, безумовно, передбачає творчий підхід як при розробці управлінських рішень, так і для мотивування персоналу щодо необхідних дій.

Мета статті - виявлення атрибутів креативного менеджера шляхом аналізу проблеми творчого потенціалу організації - обумовлює конкретні завдання дослідження: розглянути різні підходи до концептуалізації поняття «креативність» 3 тим, щоб удосконалювати $\mathrm{i}$ розширити розуміння творчого характеру управління.

Об'єкт дослідження - креативні атрибути ефективного менеджера. Предметом дослідження є організаційно-економічні відносини, що виникають у процесі менеджменту інтелектуальних і творчих ресурсів у бізнес-структурах.

Для обгрунтування теоретичних положень і висновків використовуються загальнонаукові методи, зокрема системний, абстрактно-логічний підходи, а також методи формалізації, аналізу і синтезу інформації, порівняльний аналіз і експертні оцінки, графічна візуалізація фактичної інформації.

Виходячи 3 критичного синтезу теоретичних дискурсів креативного менеджменту, пропонуєтся спроба окреслити атрибути креативного менеджера. Проблематізація феномена організаційної креативності як імперативу ефективного менеджменту дозволяє виділити групи компетенцій креативного менеджера як практичний внесок.

Креативність і креативне мислення багато в чому стають синонімами таких здібностей менеджера, як гнучкість, адаптивність, мобільність, здатність до самовдосконалення. Нові унікальні життєві можливості актуалізують для менеджера такі компетенції, як здатність інтегруватися в спосіб життя іншої людини, розуміти іншого, контекстуально моделювати і відтворювати можливі екзистенційні конфігурації. Серед суттєвих атрибутів менеджерадослідника, менеджера стратегічного типу можна також виділити креативність, здатність до навчання, рефлексивність.

Ключові слова: ефективний менеджмент, креативний менеджер, креативність, інновації, організація.

\section{ЭФФЕКТИВНЫЙ МЕНЕДЖЕР: КРЕАТИВНОЕ ИЗМЕРЕНИЕ}

ШАВКУН ИРИНА ГРИГОРЬЕВНА, доктор философских наук, профессор, декан факультета менеджмента, Запорожский наџиональный университет, г. Запорожье

ДЫБЧИНСКАЯ ЯНА СТАНИСЛАВОВНА, кандидат филологических наук, доцент, заведующая кафедрой деловой коммуникащии, Запорожский нащиональный университет, 2.3апорожье

Творчество является основополагающим аспектом человеческого общества. Менеджмент как особая сфера человеческой деятельности, безусловно, предполагает творческий подход 
Shavkun, I. and Dybchinska, Ya. (2019). "Efficient manager: creative dimension", Management and entrepreneurship: trends of development, 2 (08), pp. 47-59. doi: https://doi.org/10.26661/2522-1566/2019-2/08-04

как при разработке управленческих решений, так и для мотивирования персонала к необходимым действиям.

Цель статьи - выявление атрибутов креативного менеджера путем анализа проблемы творческого потенциала организации - обусловливает конкретные задачи исследования: рассмотреть различные подходы к концептуализации понятия творчества с тем, чтобы уточнить и расширить понимание творческого характера менеджмента.

Объект исследования - креативные атрибуты эффективного менеджера. Предметом исследования являются организационно-экономические отношения, возникающие в процессе менеджмента интеллектуальных и творческих ресурсов в бизнес-структурах.

Для обоснования теоретических положений и выводов используются общенаучные методы, в том числе системный, абстрактно-логический подходы, а также методы формализации, анализа и синтеза информации, сравнительный анализ и экспертные оценки, графическая визуализация фактической информации.

Исходя из критического синтеза теоретических дискурсов креативного менеджмента, предпринята попытка охарактеризовать атрибуты, креативного менеджера. Проблематизация феномена организационной креативности как императива эффективного менеджмента позволяет выделить группы компетенций креативного менеджера как практический вклад.

Креативность и креативное мышление во многом становятся синонимами таких способностей менеджера, как гибкость, адаптивность, мобильность, способность к самосовершенствованию. Новые уникальные жизненные возможности актуализируют для менеджера такие компетенции, как способность интегрироваться в образ жизни другого человека, понимать другого, контекстуально моделировать и воспроизводить возможные экзистенциальные конфигурации. Среди существенных атрибутов менеджера-исследователя, менеджера стратегического типа можно также выделить креативность, обучаемость, рефлексивность.

Ключевые слова: эффективный менеджмент, креативный менеджер, креативность, инновации, организация. 